No 4078

Studia nad Autorytaryzmem i Totalitaryzmem 43, nr 4 Wrocław 2021

https://doi.org/10.19195/2300-7249.43.4.2

\author{
ALEKSANDRA BUDNIAK-ROGALA \\ ORCID: 0000-0003-1391-3506 \\ Uniwersytet Wrocławski \\ aleksandra.budnik-rogala@uwr.edu.pl
}

\title{
Arbitraż w posttotalitarnych czasach PRL - uwagi wybrane na tle zakresu podmiotowego dopuszczal- ności arbitrażu (dawny art. 697 § 3 i 4 k.p.c.)
}

Słowa kluczowe: zakres dopuszczalności arbitrażu, podmiotowy zakres dopuszczalności arbitrażu, zdolność arbitrażowa, jednostki gospodarki uspołecznionej, sądownictwo polubowne w czasach PRL.

\section{ARBITRATION IN THE POST-TOTALITARIAN ERA OF THE POLISH PEOPLE'S REPUBLIC - SELECTED REMARKS ON THE OBJECTIVE SCOPE OF ADMISSIBILITY OF ARBITRATION (FORMER ARTICLE $697 \S 3$ AND 4 OF THE CIVIL PROCEDURE CODE)}

\begin{abstract}
This elaboration is an attempt to introduce an interpretation of former Art. $697 \S 3$ and 4 of the Civil Procedure Code regarding admissibility of concluding agreements for submitting disputes to an arbitration court by social economy entities. The analyzed provisions provided relevant limitations of the objective scope of admissibility of arbitration regarding said social economy entities - both in domestic and international transactions. It involved especially with the establishment of the State Economic Arbitral Institution. The solutions adopted by the legislator were undoubtedly the result of applying the principles of the socio-economic regime of the post-totalitarian Polish People's Republic.
\end{abstract}

Keywords: scope of admissibility of arbitration, objective scope of admissibility of arbitration, ability of arbitration, social economy entities, arbitration in the era of the Polish People's Republic. 


\section{Uwagi wstępne}

Sądownictwo polubowne zwane jest także sądownictwem arbitrażowym albo po prostu arbitrażem ${ }^{1}$. W doktrynie przyjmuje się, że „sądem polubownym [...] jest sąd niepaństwowy, powołany wolą stron do rozstrzygnięcia sporu, a mający oparte na ustawie prawo ferowania wyroku"2. Podnosi się przy tym równocześnie, że podstawę determinującą działalność sądów arbitrażowych stanowią wola stron i dozwalający przepis ustawy ${ }^{3}$. Określenie zakresu dopuszczalności postępowania arbitrażowego (w ujęciu podmiotowym i przedmiotowym) wykazuje kluczowe znaczenie dla sądownictwa polubownego. Pozwala bowiem ustalić krąg podmiotów, które mogą brać udział w postępowaniu przed sądem polubownym. Determinuje również zakres spraw, które mogą zostać poddane orzecznictwu sądu arbitrażowego ${ }^{4}$.

Regulacje sądownictwa polubownego ulegały ustawicznym modyfikacjom między innymi z uwagi na następujące w Polsce zmiany ustroju państwowego ${ }^{5}$. W okresie PRL obowiązujący ustrój polityczny i społeczno-gospodarczy

${ }^{1}$ E. Wengerek, M. Tyczka, Sadownictwo polubowne w handlu zagranicznym i międzynarodowym obrocie morskim, „Przegląd Ustawodawstwa Gospodarczego” 1968, nr 6, s. 212; S. Dalka, Sądownictwo polubowne PRL, Warszawa 1987, s. 15; P. Michalska, Uwagi o pojęciu i roli sądów polubownych ze szczególnym uwzględnieniem okresu Polski Ludowej, [w:] Postępowanie polubowne $w$ dziejach, red. P. Jurek, Wrocław 2006, s. 133.

2 Tak K. Potrzobowski, W. Żywicki, Sadownictwo polubowne. Komentarz dla potrzeb prakty$k i$, Warszawa 1961, s. 11; a także K. Potrzobowski, Sąd polubowny wedtug Kodeksu postępowania cywilnego, Warszawa 1981, s. 7; oraz S. Dalka, op. cit., s. 15 i przywołany przez tych wszystkich autorów R. Kuratowski, Sądownictwo polubowne, Warszawa 1932, s. 4.

3 Tak W. Siedlecki, Postępowanie cywilne. Część szczegółowa, Warszawa 1959, s. 375; idem, Postepowanie cywilne. Zarys wyktadu, Warszawa 1977, s. 495. Podobnie S. Dalka, [w:] Kodeks postepowania cywilnego. Komentarz, red. K. Piasecki, Warszawa 2002, komentarz przed art. 697 k.p.c., nb 1, s. 789-790. Zob. też P. Michalska, op. cit., s. 133.

${ }^{4}$ Aktualnie dla określenia zakresu dopuszczalności arbitrażu w ujęciu podmiotowym i przedmiotowym stosuje się (odpowiednio) pojęcia zdolności i zdatności arbitrażowej. Szerzej zob. A. Budniak-Rogala, Charakter prawny zapisu na są polubowny w postępowaniu cywilnym, Wrocław 2015, s. 58-59 i 336-337 wraz z przywołaną tam literaturą. Prezentowana konwencja pojęciowa przyjęła się powszechnie we współczesnej literaturze arbitrażu, a jej inicjatorem był A.W. Wiśniewski. Por. idem, Rozstrzyganie sporów korporacyjnych spótek kapitałowych przez sady polubowne - perspektywa ustawowego rozstrzygnięcia, cz. 1, „Prawo Spółek” 2005, nr 4, s. 10; idem, Międzynarodowy arbitraz handlowy. Status prawny arbitrażu i arbitrów, Warszawa 2011, s. 174-175 i 181; idem, Zdolność i zdatność arbitrażowa, [w:] System prawa handlowego, t. 8. Arbitraż handlowy, red. A. Szumański, Warszawa 2015, nb 1, 2 i 5, s. 279-280 oraz nb 15, s. 283.

5 Pojęcie ustroju państwowego oznacza całokształt organizacji państwa i metod działania władzy państwowej, przy czym ustrój ten dzieli się na ustrój polityczny i ustrój społeczno-gospodarczy. Ustrój polityczny to prawnoinstytucjonalny wyraz struktury i funkcjonowania władzy publicznej. Z kolei pod pojęciem ustroju społeczno-gospodarczego należy rozumieć materialne warunki życia społecznego, strukturę własnościową oraz funkcjonowanie gospodarki finansów publicznych. Tak i więcej zob. B. Banaszak, Prawo konstytucyjne, Warszawa 2017, s. 11-13. 
wykazywał szczególnie istotne oddziaływanie na treść i wykładnię obowiązujących wówczas regulacji prawnych. Przedstawiciele doktryny podnosili, że ustrój PRL

jest to ustrój państwa demokracji ludowej, zmierzającej własną drogą do socjalizmu. Jest to ustrój, w którym władza należy do ludu pracującego miast i wsi (art. 1 Konstytucji PRL ${ }^{6}$ ). Prawa PRL są wyrazem interesów i woli ludu pracującego, a ścisłe ich przestrzeganie jest podstawowym obowiązkiem każdego organu państwa i każdego obywatela (art. 4 Konstytucji PRL) ${ }^{7}$.

W konsekwencji PRL - w zależności od konkretnego okresu, przy czym linię demarkacyjną w przedmiotowym zakresie stanowił rok 1956 — określa się obecnie mianem państwa totalitarnego, względnie posttotalitarnego ${ }^{8}$. Pojęcie demokracji ludowej utożsamiane jest zaś niekiedy z pojęciem demokracji totalitarnej ${ }^{9}$. W czasach PRL w piśmiennictwie wskazywano również, że ustrój polityczny państwa wyznaczany jest przez aktualny układ stosunków gospodarczo-społecznych, a normy prawne muszą odpowiadać w swej treści i w zakresie swej realizacji interesom klasy rządzącej w państwie ${ }^{10}$. W PRL obowiązywał model gospodarki centralnie planowanej, opartej na uspołecznionych środkach produkcji (art. 7 ust. 1 i 3 Konstytucji PRL). Nie pozostawało to z pewnością bez

${ }^{6}$ Konstytucja Polskiej Rzeczypospolitej Ludowej uchwalona przez Sejm Ustawodawczy w dniu 22 lipca 1952 roku (Dz.U. z 1952 r. Nr 33, poz. 232, dalej: Konstytucja PRL).

7 Tak W. Siedlecki, [w:] J. Jodłowski, W. Siedlecki, Postępowanie cywilne. Część ogólna, Warszawa 1958, s. 5.

${ }^{8}$ N. Davies wyodrębnia w ramach historii politycznej PRL trzy podstawowe fazy: pierwszą — w latach 1944-1948 — okres stopniowej budowy demokracji ludowej, drugą — w latach 19481956 — okres narzucania Polsce stalinizmu oraz trzecią — od roku 1956 — okres panowania aparatu „narodowego komunizmu”. Idem, Boże igrzysko, Kraków 2008, s. 1011. Współcześnie w doktrynie sporna pozostaje kwestia, czy PRL była państwem totalitarnym począwszy od roku 1944 aż po rok 1989. Szczegółowo zob. A. Friszke, Spór o PRL w III Rzeczypospolitej (1989-2001), „Pamięć i Sprawiedliwość" 2002, nr 1, s. 18-24 wraz z przywołaną tam literaturą. W piśmiennictwie wskazuje się, że ustrój PRL podlegał nieustannej ewolucji. Przełomowe znaczenie (mające istotny wpływ na kształt obowiązującego wówczas systemu) przypisuje się wydarzeniom politycznym roku 1956. W konsekwencji przyjmuje się, że PRL w okresie stalinizacji — a więc do odwilży w roku 1956 była państwem totalitarnym. Ustrój polityczny PRL po przełomie październikowym — a zatem po roku 1956 - określa się natomiast mianem posttotalitarnego autorytaryzmu. Zob. przykładowo L. Mażewski, Posttotalitarny autorytaryzm PRL 1956-1989, Warszawa-Biała Podlaska 2010; A. Walicki, PRL i skok do neoliberalizmu. Jaruzelski, Solidarność, zdrada elit, Warszawa 2021. Ostatecznie warto jednak podkreślić, iż wprowadzenie dyferencjacji w przedmiotowym zakresie stanowi element swoistej konwencji związanej ze sposobem definiowania i określania konstruktywnych elementów pojęć (czy też — inaczej ujmując — kategorii) totalitaryzmu i autorytaryzmu. Szerzej zob. H. Izdebski, Totalitaryzm i terminy pokrewne w naukach społecznych oraz $w$ polskim języku prawnym i prawniczym, „Studia nad Autorytaryzmem i Totalitaryzmem” 38, 2016, nr 4, s. $31 \mathrm{n}$.

9 Por. przykładowo R. Balicki, A. Ławniczak, Polska Ludowa jako przypadek prawno-polityczny, [w:] Z historii ustroju i konstytucjonalizmu Polski. Ksiega jubileuszowa dedykowana w osiemdziesiata rocznice Urodzin Profesora Mariana Kallasa, red. D. Makiłła, M. Wilczek-Karczewska, Warszawa 2018, s. 51.

10 W. Siedlecki, [w:] J. Jodłowski, W. Siedlecki, Postępowanie cywilne..., s. 5. 
wpływu na sposób kształtowania obowiązujących ówcześnie regulacji prawnych — w tym w szczególności z zakresu postępowania arbitrażowego.

W okresie poprzedzającym uchwalenie Kodeksu postępowania cywilnego z 1964 roku Komisja Kodyfikacyjna rozważała zagadnienie celowości utrzymania instytucji sądownictwa polubownego. Argumentowano bowiem, że w gospodarce socjalistycznej sądownictwo arbitrażowe nie ma racji bytu ${ }^{11}$. Ostatecznie ustawa z dnia 17 października 1964 roku - Kodeks postępowania cywilnego ${ }^{12}$ zawierata jednak przepisy dotyczące sądownictwa polubownego ${ }^{13}$.

$\mathrm{Na}$ szczególną uwagę $\mathrm{w}$ przedmiotowym zakresie zasługuje regulacja $\mathrm{z}$ dawnego (dalej: d.) art. 697 k.p.c. determinująca zasadniczo zakres dopuszczalności postępowania arbitrażowego w ujęciu przedmiotowym (d. art. 697 § 1 k.p.c.) i podmiotowym (d. art. 697 § 3 i 4 k.p.c.). Zgodnie z treścią d. art. 697 § 1 k.p.c. strony w granicach zdolności do samodzielnego zobowiązywania się mogły poddać pod rozstrzygnięcie sądu polubownego spory o prawa majątkowe, z wyjątkiem sporów o alimenty i ze stosunku pracy. Umowę o poddanie sporu pod rozstrzygnięcie sądu polubownego ustawodawca konsekwentnie określał mianem zapisu na sąd polubowny (por. d. art. $698 \S 1$ in principio k.p.c.) ${ }^{14}$. W myśl d. art. $697 \S 3$ k.p.c. rozporządzenie Rady Ministrów miało określić wypadki, w których jednostki gospodarki uspołecznionej będą mogły zawierać umowy o poddanie sporu pod rozstrzygnięcie sądu polubownego. $Z$ kolei na zasadzie d. art. 697 § 4 k.p.c., poza wypadkami określonymi stosownie do $\S 3$, jednostki gospodarki uspołecznionej mogły zawierać umowy o poddanie pod rozstrzygnięcie sądu polubownego sporów ze stronami zamieszkałymi lub mającymi siedzibę za granicą. W nawiązaniu do powołanych regulacji wypada podkreślić, że w dacie wejścia w życie Kodeksu postępowania cywilnego z 1964 roku $^{15}$ przepis d. art. 697 k.p.c. przewidywał w $\S 3$ i 4 adekwatne ograniczenia zakresu podmiotowego dopuszczalności arbitrażu odnoszące się wyłącznie do jednostek gospodarki uspołecznionej ${ }^{16}$. Treść i wykładnia analizowanych przepisów wykazywała zatem szczególnie relewantne

11 Por. W. Siedlecki, Postępowanie cywilne. Część szczegółowa..., s. 377; oraz K. Potrzobowski, op. cit., s. 5-6; a także S. Dalka, Sąownictwo polubowne..., s. 13 i przywołane przez tych dwóch ostatnich autorów: Projekt Kodeksu postępowania cywilnego PRL, Warszawa 1955, s. 195; oraz Projekt Kodeksu postępowania cywilnego PRL, Warszawa 1964, s. 210. Zob. też P. Michalska, op. cit., s. 139.

12 Dz.U. z 1964 r. Nr 43, poz. 296, dalej: Kodeks postępowania cywilnego z 1964 roku lub k.p.c. z 1964 roku.

13 Art. 695-715.

14 Rozważania prowadzone w ramach niniejszego artykułu będą się zasadniczo skupiały na interpretacji regulacji z art. $697 \S 3$ i 4 k.p.c. Poza zakresem analizy pozostanie natomiast wykładnia przepisu art. $697 \S 1$ k.p.c. Odniesienie do przedmiotowej kwestii stanowiłoby bowiem (nieuzasadnione) odejście od zasadniczej tematyki opracowania.

15 Regulacje k.p.c. z 1964 roku weszły w życie w dniu 1 stycznia 1965 roku.

16 B. Dobrzański, [w:] B. Dobrzański et al., Kodeks postępowania cywilnego. Komentarz, t. 1, Warszawa 1969, komentarz do art. 697 k.p.c., pkt 1, s. 969. 
powiązanie z obowiązującym w posttotalitarnych czasach PRL ustrojem społeczno-gospodarczym.

\section{Jednostki gospodarki uspołecznionej jako podmiot arbitrażu państwowego}

Istnienie jednostek gospodarki uspołecznionej pozostawało w ścisłym związku z aktualnymi założeniami ustroju państwowego PRL. W okresie gospodarki planowanej została wprowadzona przez państwo kategoria jednostki gospodarczej, przy czym pojęcie to oznaczało każdą jednostkę organizacyjną powołaną do prowadzenia stałej działalności gospodarczej. Jednostki gospodarcze dzielono na jednostki gospodarki uspołecznionej i jednostki gospodarki nieuspołecznionej. Dyferencjacja w przedmiotowym zakresie stanowiła efekt dychotomicznego podziału obrotu gospodarczego na uspołeczniony i nieuspołeczniony dokonanego przede wszystkim na podstawie kryterium własnościowego ${ }^{17}$. Kategoria podmiotów gospodarki uspołecznionej obejmowała zatem wyodrębnione pod względem majątkowym i względnie samodzielne przedsiębiorstwa państwowe oraz spółdzielnie i inne społeczne organizacje gospodarcze ${ }^{18}$.

System społecznej gospodarki planowej wpływał na szczególny charakter stosunków, które powstawały pomiędzy jednostkami gospodarki uspołecznionej, wymagających swoistego podejścia przy rozstrzyganiu sporów powstałych na tle tych stosunków $^{19}$. W związku z tym w dniu 1 października 1949 roku weszły w życie postanowienia dekretu $\mathrm{z}$ dnia 5 sierpnia 1949 roku o państwowym arbitrażu gospodarczym ${ }^{20}$. Powołany dekret został uchylony z dniem 1 grudnia 1975 roku — wtedy zaczęła bowiem obowiązywać ustawa z dnia 23 października 1975 roku o Państwowym Arbitrażu Gospodarczym ${ }^{21}$. Instytucja arbitrażu państwowego ustanowiona

17 Por. K. Kruczalak, Prawo handlowe. Zarys wyktadu, Warszawa 1996, s. 41-42 i A. Kidyba, Prawo handlowe, Warszawa 2020, s. 18. Zob. też T. Szanciło, Przedsiębiorca w prawie polskim, „Przegląd Prawa Handlowego” 2005, nr 3, s. 4. Odnośnie do stosowanej nomenklatury pojęciowej szczegółowo por. przykładowo S. Włodyka, Prawo gospodarcze. Zarys systemu. Część ogólna, t. 1, Warszawa 1981, s. 105-110; oraz idem, Prawo gospodarcze. Zarys systemu. Część ogólna, t. 2, Warszawa 1982 , s. 216-217.

18 Tak W. Berutowicz, Postępowanie cywilne $w$ zarysie, Warszawa 1984, s. 31. Podobnie P. Michalska, op. cit., s. 140.

19 Szerzej zob. W. Siedlecki, Postępowanie cywilne. Zarys wyktadu..., s. 470; W. Berutowicz, op. cit., s. 31. Por. też P. Michalska, op. cit., s. 140.

20 Tekst jedn. Dz.U. z 1961 r. Nr 37, poz. 195, dalej: dekret o państwowym arbitrażu gospodarczym lub p.a.g.d. Szerzej zob. między innymi M. Tyczka, Arbitraż i postępowanie arbitrażowe, Warszawa 1970; A. Rosienkiewicz, Postępowanie przed państwowymi komisjami arbitrażowymi, Wrocław 1975.

21 Dz.U. z 1975 r. Nr 34, poz. 183, dalej: ustawa o Państwowym Arbitrażu Gospodarczym lub p.a.g.u. Więcej por. na przykład Z. Klafkowski, A. Rosienkiewicz, Państwowy Arbitraż Gospodar- 
została $\mathrm{w}$ celu rozpoznawania i rozstrzygania sporów majątkowych $\mathrm{z}$ sektora uspołecznionego ${ }^{22}$. Powstanie arbitrażu gospodarczego związane było zatem ściśle z obowiązującym wówczas systemem planowej gospodarki socjalistycznej ${ }^{23}$.

Arbitraż państwowy cechował się licznymi odrębnościami - należało go więc całkowicie odróżnić zarówno od sądownictwa państwowego ${ }^{24}$, jak i od sądownictwa polubownego ${ }^{25}$. Konsekwentnie zatem spory pomiędzy podmiotami arbitrażu państwowego nie mogły być poddane orzecznictwu sądu arbitrażowego (por. odpowiednio art. 5 ust. 2 p.a.g.d. i art. 3 ust. 5 p.a.g.u.) ${ }^{26}$.

czy. Komentarz, Warszawa 1978; A. Rosienkiewicz, Zapobieganie i rozwiązywanie sporów między jednostkami uspotecznionymi, Wrocław 1978; K. Korzan, Arbitraż i postępowanie arbitrażowe, Warszawa 1980; S. Dalka, Postępowanie arbitrażowe, Gdańsk 1982.

22 Por. S. Włodyka, Ustawa o rozpoznawaniu przez sady spraw gospodarczych, „Państwo i Prawo" 1990, nr 3, s. 14; T. Wiśniewski, Postepowanie sadowe w sprawach gospodarczych, Kraków 1997, s. 9; idem, System postępowania sądowego w sprawach cywilnych z udziatem przedsiębiorców, [w:] System prawa handlowego, red. S. Włodyka, t. 7. Postępowanie sądowe w sprawach cywilnych z udziatem przedsiębiorców, red. T. Wiśniewski, Warszawa 2013, nb 3, s. 6-7. Zob. też J. Kozak, Sadownictwo gospodarcze, [w:] Studia z prawa gospodarczego i handlowego. Księga pamiątkowa ku czci Profesora Stanisława Włodyki, red. W. Pyzioł, Kraków 1996, s. 256-257; P. Michalska, op. cit., s. 140; J. Dąbrowska, Rozpoznawanie przez sądy spraw gospodarczych. Komentarz, Warszawa 2013, s. 9.

23 Tak M. Tyczka, op. cit., s. 10.

${ }^{24}$ Postępowanie arbitrażowe przez Państwowym Arbitrażem Gospodarczym wzorowane było wprawdzie na sądowym postępowaniu cywilnym, cechowało się jednak licznymi odrębnościami - Państwowy Arbitraż Gospodarczy nie był bowiem organem niezawisłym i podporządkowany był Radzie Ministrów. Por. T. Ereciński, M. Tomaszewski, Rozstrzyganie sporów, „Handel Zagraniczny" 1983, nr 6, s. 22. Konsekwentnie model rozstrzygania sporów między jednostkami gospodarki uspołecznionej sankcjonował przepis d. art. 2 ust. 2 k.p.c. w pierwotnym brzmieniu, który wyłączał z drogi sądowej sprawy cywilne między jednostkami gospodarki uspołecznionej należące do Państwowego Arbitrażu Gospodarczego lub arbitrażu resortowego. Zob. J. Kozak, op. cit., s. 257. Powołany przepis został uchylony na mocy ustawy z dnia 24 maja 1989 roku o rozpoznawaniu przez sądy spraw gospodarczych (Dz.U. z 1989 r. Nr 33, poz. 175), która weszła w życie w dniu 1 października 1989 roku.

${ }^{25}$ Państwowy Arbitraż Gospodarczy wbrew swej nazwie nigdy nie był sądem polubownym (arbitrażowym), lecz instytucją państwową, której naczelnym zadaniem było umacnianie praworządności i porządku prawnego w stosunkach między jednostkami gospodarki uspołecznionej. Tak J. Kozak, op. cit., s. 257. Podobnie T. Wiśniewski, System postępowania sadowego..., nb 6, s. 8-9.

${ }^{26} \mathrm{Na}$ zasadzie art. 3 ust. 5 p.a.g.u. umowa o poddanie pod rozstrzygnięcie sądu polubownego sporu, którego rozpoznanie należało do Państwowego Arbitrażu Gospodarczego, była bowiem nieważna. Zob. K. Potrzobowski, op. cit., s. 9; S. Dalka, Sadownictwo polubowne..., s. 41. Analogiczne wyłączenie statuowała również wcześniejsza regulacja $\mathrm{z}$ art. 5 ust. 2 p.a.g.d., zgodnie z którą nieważna była umowa o poddanie sporów ulegających rozpoznaniu przez państwowe komisje arbitrażowe pod rozstrzygnięcie sądów polubownych. Por. K. Potrzobowski, W. Żywicki, op. cit., s. 12; E. Wengerek, M. Tyczka, op. cit., s. 216; B. Dobrzański, op. cit., komentarz do art. 697 k.p.c., pkt 3, s. 975. 


\section{Zawieranie przez jednostki gospodarki uspołecznionej umów o poddanie sporów pod rozstrzygnięcie sądu polubownego}

Na podstawie regulacji z d. art. $697 \S 3$ i 4 k.p.c. ustawodawca w odmienny sposób unormował dopuszczalność zawierania zapisu na sąd polubowny przez jednostki gospodarki uspołecznionej w zależności od tego, czy chodziło o umowy w obrocie wewnętrznym (d. art. 697 § 3 k.p.c.), czy też międzynarodowym, a więc umowy ze stronami zamieszkałymi lub mającymi siedzibę za granicą (d. art. 697 $\S 4$ k.p.c. $)^{27}$.

\subsection{Umowy w obrocie wewnętrznym (d. art. 697 § 3 k.p.c.)}

Na zasadzie d. art. 697 § 3 k.p.c. wypadki, w których jednostki gospodarki uspołecznionej będą mogły zawierać umowy o poddanie sporu pod rozstrzygnięcie sądu polubownego, miało określić rozporządzenie Rady Ministrów. Na tle wykładni d. art. $697 \S 3$ k.p.c. przedstawiciele doktryny podnosili zatem pierwotnie, że

wobec tego chodzić będzie z reguły o zawieranie umów z podmiotami nie będącymi jednostkami gospodarki uspołecznionej. Dopuszczalna będzie taka umowa także w wypadku (oczywiście jeżeli tak postanowi rozporządzenie Rady Ministrów), gdy jedną ze stron będzie jednostka gospodarki uspołecznionej nie podlegająca państwowemu arbitrażowi gospodarczemu [... $]^{28}$.

Równocześnie (z uwagi na wyraźne wyłączenie statuowane na podstawie regulacji z art. 5 ust. 2 p.a.g.d.) w piśmiennictwie uznawano, że chodzić tu będzie głównie o zawieranie umów o poddanie sporów pod rozstrzygnięcie sądu polubownego z podmiotami niepodlegającymi arbitrażowi państwowemu ${ }^{29}$. Podkreślano przy tym ostatecznie, że prawie wszystkie jednostki gospodarki uspołecznionej będą podlegały jurysdykcji państwowego arbitrażu gospodarczego. $\mathrm{Z}$ reguły zatem poddawanie pod rozstrzygnięcie sądów polubownych sporów między tymi jednostkami będzie niedopuszczalne ${ }^{30}$.

Rozporządzenie, o którym mowa w d. art. 697 § 3 k.p.c., nie zostało jednak wydane $^{31}$. W związku z tym w piśmiennictwie pozostawało sporne, czy jednostki gospodarki uspołecznionej mogą dokonywać zapisów na sąd polubowny z krajowymi

27 E. Wengerek, M. Tyczka, op. cit., s. 213; B. Dobrzański, op. cit., komentarz do art. 697 k.p.c., pkt 3, s. 974; T. Ereciński, [w:] Kodeks postępowania cywilnego z komentarzem, t. 3, red. J. Jodłowski, K. Piasecki, Warszawa 1989, komentarz do art. 697 k.p.c., nb 4, s. 1064.

28 Tak B. Dobrzański, op. cit., komentarz do art. 697 k.p.c., pkt 3, s. 975.

29 W. Siedlecki, Postępowanie cywilne. Zarys wyktadu..., s. 497.

30 E. Wengerek, M. Tyczka, op. cit., s. 216.

${ }^{31}$ K. Potrzobowski, op. cit., s. 8; M. Tomaszewski, Klauzule arbitrażowe w kontaktach handlu zagranicznego sektora nieuspołecznionego, „Handel Zagraniczny” 1984, $\mathrm{nr}$ 2, s. 22; S. Dalka, op. cit., s. 40-41; T. Ereciński, Kodeks postępowania cywilnego..., komentarz do art. 697 k.p.c., nb 4, s. 1064. 
jednostkami gospodarki nieuspołecznionej ${ }^{32}$. W literaturze prezentowany był pogląd, którego przedstawiciele uznawali, że brak wspomnianego rozporządzenia praktycznie przekreśla możliwość sporządzania zapisów na sąd polubowny w tego rodzaju sprawach ${ }^{33}$. Część autorów wyrażała jednak pozytywne stanowisko w przedmiotowym zakresie - oczywiście w odniesieniu do sporów o roszczenia majątkowe i z zastrzeżeniem adekwatnych wyłączeń odnoszących się do spraw ze stosunku pracy i o alimenty (na zasadzie d. art. $697 \S 1$ k.p.c.) ${ }^{34}$. Niektórzy przedstawiciele doktryny prezentujący analizowany pogląd podnosili przy tym równocześnie, że możliwość dokonywania zapisów na sąd polubowny w odniesieniu do sporów o roszczenia majątkowe obejmuje również jednostki uspołecznione, które nie są podmiotami postępowania przed organami Państwowego Arbitrażu Gospodarczego $0^{35}$.

\subsection{Umowy w obrocie międzynarodowym (d. art. 697 § 4 k.p.c.)}

Wyjątek od ograniczenia podmiotowego dopuszczalności arbitrażu w stosunku do jednostek gospodarki uspołecznionej przewidywał d. art. 697 § 4 k.p.c. ${ }^{36}$ $\mathrm{Na}$ zasadzie d. art. $697 \S 4$ k.p.c., poza wypadkami określonymi stosownie do $\S 3$, jednostki gospodarki uspołecznionej mogły zawierać umowy o poddanie pod rozstrzygnięcie sądu polubownego sporów ze stronami zamieszkałymi lub mającymi siedzibę za granicą. W piśmiennictwie podkreślano, że powołana regulacja przyznaje wprost możność zawierania umów o poddanie sporów pod rozstrzygnięcie sądu polubownego przez jednostki gospodarki uspołecznionej w obrocie międzynarodowym ${ }^{37}$. Część autorów podnosiła przy tym równocześnie, że analizowany przepis nie wprowadza żadnych ograniczeń w tym przedmiocie ${ }^{38}$.

W literaturze wskazywano, że jeżeli chodzi o obrót międzynarodowy, to ze stronami zamieszkałymi lub mającymi siedzibę za granicą jednostki gospodarki uspołecznionej mogą zawierać umowy o poddanie sporów pod rozstrzygnięcie sądu polubownego na zasadach ogólnych — a więc przy zastosowaniu reguł statuowanych na podstawie regulacji z d. art. 697 § 1 k.p.c. Dotyczyło to jednak tylko umów o poddanie sporu sądowi polubownemu działającemu w kraju. W przypadku sądów arbitrażowych działających za granicą w analizowanym zakresie zastosowanie znajdowała bowiem regulacja $\mathrm{z}$ d. art. $1105 \S 3 \mathrm{w}$ zw. z $\S 1$ k.p.c. Powołany

32 S. Dalka, Sadownictwo polubowne..., s. 40-41.

33 Por. B. Dobrzański, op. cit., s. 1010; K. Potrzobowski, Sąd polubowny..., s. 8-9; T. Ereciński, M. Tomaszewski, Rozstrzyganie sporów..., s. 23; T. Ereciński, [w:] Kodeks postępowania cywilnego..., komentarz do art. 697 k.p.c., nb 4, s. 1064; M. Tomaszewski, Klauzule arbitrażowe..., s. 22.

34 Por. E. Wengerek, M. Tyczka, op. cit., s. 216 i S. Dalka, Sadownictwo polubowne..., s. 41.

35 S. Dalka, Sąownictwo polubowne..., s. 41.

${ }^{36}$ K. Potrzobowski, op. cit., s. 9.

37 Tak W. Siedlecki, Postępowanie cywilne. Zarys wykładu..., s. 497.

${ }^{38}$ K. Potrzobowski, op. cit., s. 9. 
przepis w pierwotnym brzmieniu przewidywał możliwość poddania przez polską jednostkę gospodarki uspołecznionej sądowi polubownemu działającemu za granicą tylko sporów o prawa majątkowe w zakresie zobowiązań, pod warunkiem że taki zapis był skuteczny według prawa tego państwa, do którego należał kontrahent, oraz gdy sprawa nie należała do wyłącznej jurysdykcji sądów polskich ${ }^{39}$.

W konsekwencji (mając na względzie wymogi wynikające z treści d. art. 697 $\S 1$ k.p.c.) w doktrynie wskazywano, iż

z tego wynika, że nie ma przeszkód, żeby nasze jednostki gospodarki uspołecznionej zawierały umowy o poddanie każdego sporu majątkowego (z wyjątkiem spraw ze stosunku pracy) ze stronami zamieszkałymi lub mającymi siedzibę za granicą pod rozstrzygnięcie sądu polubownego działającego w Polsce ${ }^{40}$. [...] Możliwość taką mają również polskie osoby prawne i fizyczne, nie będące jednostkami gospodarki uspołecznionej z tym zastrzeżeniem, że względem osób fizycznych należy wziąć pod uwagę jeszcze warunek wyłączenia spraw o alimenty ${ }^{41}$.

W piśmiennictwie podkreślano bowiem, że analizowany przepis d. art. 697 $\S 4$ k.p.c.

nie może być interpretowany a contrario, tj. w takim sensie, że tylko jednostki gospodarki uspołecznionej mogą zawrzeć umowę o sąd polubowny ze stroną zamieszkałą lub mającą siedzibę za granicą. Przepis ten stanowi bowiem wyjątek od zasadniczej niedopuszczalności zawierania umowy o sąd polubowny, ale tylko przez jednostki gospodarki uspołecznionej. Pomijając natomiast jednostki gospodarki uspołecznionej wszelkie inne podmioty, w granicach swej zdolności do samodzielnego zobowiązywania się, mogą zawierać umowy o sąd polubowny w zakresie wskazanym w d. art. 697 § 1 k.p.c., bez względu na to, jakie jest ich obywatelstwo i gdzie mają zamieszkanie lub siedzibę ${ }^{42}$.

\section{Konkluzje}

Syntetyczna analiza przeprowadzonej wykładni regulacji z d. art. 697 § 3 i 4 k.p.c. prowadzi do następujących konkluzji.

39 Por. S. Dalka, Sądownictwo polubowne..., s. 41-42; T. Ereciński, [w:] Kodeks postępowania cywilnego..., komentarz do art. 697 k.p.c., nb 7, s. 1065. Zob. też E. Wengerek, M. Tyczka, op. cit., s. 216; K. Potrzobowski, op. cit., s. 9; M. Tomaszewski, Klauzule arbitrażowe..., s. 23.

40 Tak S. Dalka, Sądownictwo polubowne..., s. 42 i przywołani przez tego autora E. Wengerek, M. Tyczka, op. cit., s. 216.

41 Tak S. Dalka, Sadownictwo polubowne..., s. 42 i przywołany przez tego autora M. Tomaszewski, Klauzule arbitrażowe..., s. 23; oraz E. Wengerek, M. Tyczka, op. cit., s. 216. Więcej na ten temat zob. S. Dalka, Sąownictwo polubowne..., s. 42 i T. Ereciński, [w:] Kodeks postepowania cywilnego..., komentarz do art. 697 k.p.c., nb 6, s. 1065; oraz przywołani przez tych autorów T. Ereciński, M. Tomaszewski, Rozstrzyganie sporów..., s. 23.

42 Tak T. Ereciński, [w:] Kodeks postepowania cywilnego..., komentarz do art. 697 k.p.c., nb 5, s. 1064-1065 wraz z przywołaniem stanowiska M. Tomaszewskiego, Klauzule arbitrażowe..., s. $22-23$. 
Primo, przepis d. art. $697 \S 3$ k.p.c. przewidywał kompetencję do określenia na mocy rozporządzenia Rady Ministrów wypadków, w których jednostki gospodarki uspołecznionej będą mogły zawierać umowy o poddanie sporu pod rozstrzygnięcie sądu arbitrażowego. Rozporządzenie to nie zostało jednak nigdy wydane. Co więcej, w okresie PRL orzecznictwu sądów polubownych nie mogły być poddawane spory pomiędzy podmiotami arbitrażu państwowego (por. art. 5 ust. 2 p.a.g.d. i art. 3 ust. 5 p.a.g.u.). $\mathrm{W}$ ostatecznym efekcie skutkowało to de facto (praktycznie całkowitym) wyłączeniem dopuszczalności postępowania arbitrażowego w odniesieniu do obrotu uspołecznionego.

Secundo, w przepisie d. art. $697 \S 4$ k.p.c. przewidziano wprawdzie wyjątek od ograniczenia podmiotowego dopuszczalności arbitrażu w stosunku do jednostek gospodarki uspołecznionej odnoszący się do umów o poddanie sporów pod rozstrzygnięcie sądu polubownego w obrocie międzynarodowym. W konsekwencji jednostki sektora uspołecznionego mogły zawierać umowy o poddanie pod rozstrzygnięcie sądu polubownego sporów ze stronami zamieszkałymi lub mającymi siedzibę za granicą na zasadach ogólnych statuowanych na podstawie regulacji z d. art. $697 \S 1$ k.p.c. Reguła to odnosiła się jednak wyłącznie do sądów polubownych działających w kraju. W odniesieniu do sytuacji, w których spór taki miał zostać poddany orzecznictwu sądu polubownego działającego za granicą, ustawodawca wprowadzał bowiem relewantne ograniczenia na zasadzie d. art. $1105 \S 3$ k.p.c.

W związku z powyższym wypada stwierdzić, że w posttotalitarnym okresie PRL ustawodawca przewidywał $\mathrm{w}$ istocie relewantne ograniczenia odnoszące się do podmiotowego zakresu dopuszczalności arbitrażu - w obrocie zarówno krajowym, jak i międzynarodowym. W literaturze podkreślano wprawdzie, że ówczesna praktyka potwierdziła pozytywne stanowisko w odniesieniu do sądownictwa arbitrażowego ${ }^{43}$. Mając na względzie treść i wykładnię analizowanych regulacji z d. art. $697 \S 3$ i 4 k.p.c., nie sposób nie przyznać jednak słuszności przedstawicielom doktryny, którzy podnosili, że w okresie PRL doszło niewątpliwie do marginalizacji znaczenia sądownictwa polubownego ${ }^{44}$.

Regulacje z d. art. 697 § 3 i 4 k.p.c. zostały uchylone na mocy ustawy z dnia 24 maja 1989 roku o rozpoznawaniu przez sądy spraw gospodarczych ${ }^{45}$. Wiązało się to niewątpliwie ze zrównaniem pozycji gospodarczej jednostek gospodarki uspołecznionej z podmiotami gospodarczymi innych sektorów gospodarki narodowej oraz z likwidacją Państwowego Arbitrażu Gospodarczego ${ }^{46}$. Odrębność

43 Por. W. Siedlecki, Postępowanie cywilne. Część szczegółowa..., s. 377; K. Potrzobowski, op. cit., s. 5-6; S. Dalka, Sadownictwo polubowne..., s. 13-14; P. Michalska, op. cit., s. 139.

44 W. Siedlecki, Postępowanie cywilne. Część szczegółowa..., s. 376-377.

45 Dz.U. z 1989 r. Nr 33, poz. 175, dalej: ustawa o rozpoznawaniu przez sądy spraw gospodarczych.

46 Tak S. Dalka, [w:] Kodeks postępowania cywilnego..., komentarz do art. 697 k.p.c., nb 7 , s. 797. Por. też J. Kozak, op. cit., s. 257. Ustawa o Państwowym Arbitrażu Gospodarczym została uchylona również ustawą z dnia 24 maja 1989 roku o rozpoznawaniu przez sądy spraw gospodarczych. 
jednostek reprezentujących sektor gospodarki uspołecznionej utraciła swoje znaczenie. W konsekwencji przestała istnieć potrzeba funkcjonowania osobnej, pozasądowej instytucji zajmującej się rozstrzyganiem sporów między tymi jednostkami ${ }^{47}$. Wejście w życie ustawy o rozpoznawaniu przez sądy spraw gospodarczych ${ }^{48}$ skutkowało przekazaniem rozpoznawania wszystkich spraw związanych z profesjonalnym obrotem gospodarczym utworzonym w tym celu wyspecjalizowanym wydziałom sądów powszechnych (wydziałom gospodarczym), a także wyodrębnieniem postępowania w tych sprawach (postępowania odrębnego w sprawach gospodarczych $)^{49}$. W doktrynie podnoszono, że rok 1989 stanowił cezurę czasową przemian polskiego prawa procesowego związanych ze zmianami ustrojowymi ${ }^{50}$. Nie bez przyczyny podkreślano również, że analizowane zmiany miały charakter fundamentalny ${ }^{51}$. W efekcie wprowadzonych modyfikacji obowiązujące regulacje prawne nie przewidywały już adekwatnych wyłączeń w odniesieniu do zakresu podmiotowego dopuszczalności arbitrażu dotyczących jednostek gospodarki uspołecznionej. Uchylenie regulacji z d. art. 697 § 3 i 4 k.p.c. oraz przepisów ustawy o Państwowym Arbitrażu Gospodarczym wiązało się niewątpliwie z koniecznością dostosowania obowiązującego porządku prawnego do zasad transformowania gospodarki.

\section{Bibliografia}

Balicki R., Ławniczak A., Polska Ludowa jako przypadek prawno-polityczny, [w:] Z historii ustroju i konstytucjonalizmu Polski. Księga jubileuszowa dedykowana w osiemdziesiąta rocznicę Urodzin Profesora Mariana Kallasa, red. D. Makiłła, M. Wilczek-Karczewska, Warszawa 2018.

Banaszak B., Prawo konstytucyjne, Warszawa 2017.

Berutowicz W., Postępowanie cywilne w zarysie, Warszawa 1984.

Budniak-Rogala A., Charakter prawny zapisu na sąd polubowny w postępowaniu cywilnym, Wrocław 2015.

Dalka S., [w:] Kodeks postępowania cywilnego. Komentarz, red. K. Piasecki, Warszawa 2002, komentarz przed art. 697 k.p.c.

Dalka S., Postępowanie arbitrażowe, Gdańsk 1982.

Dalka S., Sadownictwo polubowne PRL, Warszawa 1987.

Davies N., Boże igrzysko, Kraków 2008.

Dąbrowska J., Rozpoznawanie przez sądy spraw gospodarczych. Komentarz, Warszawa 2013.

47 J. Kozak, op. cit., s. 257.

48 Ustawa weszła w życie 1 października 1989 roku.

49 Szczegółowo zob. J. Kozak, op. cit., s. 256 n.; S. Włodyka, Ustawa ..., s. 14 n.; T. Wiśniewski, System postępowania sądowego..., nb 8-12, s. 9-11. W tym zakresie por. też T. Wiśniewski, Postepowanie sądowe..., s. 9-10; J. Dąbrowska, Rozpoznawanie przez sądy..., s. 9-11 wraz z przywołana tam literaturą.

50 A. Jakubecki, Naczelne zasady postępowania cywilnego w świetle nowelizacji Kodeksu postępowania cywilnego, [w:] Czterdziestolecie Kodeksu postępowania cywilnego. Zjazd Katedr Postępowania Cywilnego w Zakopanem, red. A. Oklejak, Kraków 2006, s. 349.

51 Tak J. Kozak, op. cit., s. 256. 
Dobrzański B., [w:] B. Dobrzański, M. Lisiewski, Z. Resich, W. Siedlecki, Kodeks postępowania cywilnego. Komentarz, t. 1, Warszawa 1969, komentarz do art. 697 k.p.c.

Ereciński T., [w:] Kodeks postępowania cywilnego z komentarzem, t. 3, red. J. Jodłowski, K. Piasecki, Warszawa 1989, komentarz do art. 697 k.p.c.

Ereciński T., Tomaszewski M., Rozstrzyganie sporów, „Handel Zagraniczny” 1983, nr 6.

Friszke A., Spór o PRL w III Rzeczypospolitej (1989-2001), „Pamięć i Sprawiedliwość” 2002, nr 1.

Izdebski H., Totalitaryzm i terminy pokrewne w naukach społecznych oraz w polskim języku prawnym i prawniczym, „Studia nad Autorytaryzmem i Totalitaryzmem” 38, 2016, nr 4.

Jakubecki A., Naczelne zasady postępowania cywilnego w świetle nowelizacji Kodeksu postępowania cywilnego, [w:] Czterdziestolecie Kodeksu postępowania cywilnego. Zjazd Katedr Postępowania Cywilnego w Zakopanem, red. A. Oklejak, Kraków 2006.

Kidyba A., Prawo handlowe, Warszawa 2020.

Klafkowski Z., Rosienkiewicz A., Państwowy Arbitraż Gospodarczy. Komentarz, Warszawa 1978.

Korzan K., Arbitraż i postępowanie arbitrażowe, Warszawa 1980.

Kozak J., Sądownictwo gospodarcze, [w:] Studia z prawa gospodarczego i handlowego. Księga pamiątkowa ku czci Profesora Stanisława Włodyki, red. W. Pyzioł, Kraków 1996.

Kruczalak K., Prawo handlowe. Zarys wykładu, Warszawa 1996.

Kuratowski R., Sadownictwo polubowne, Warszawa 1932.

Mażewski L., Posttotalitarny autorytaryzm PRL 1956-1989, Warszawa-Biała Podlaska 2010.

Michalska P., Uwagi o pojęciu i roli sądów polubownych ze szczególnym uwzględnieniem okresu Polski Ludowej, [w:] Postępowanie polubowne w dziejach, red. P. Jurek, Wrocław 2006.

Potrzobowski K., Sad polubowny wedlug Kodeksu postepowania cywilnego, Warszawa 1981.

Potrzobowski K., Żywicki W., Sądownictwo polubowne. Komentarz dla potrzeb praktyki, Warszawa 1961.

Rosienkiewicz A., Postępowanie przed państwowymi komisjami arbitrażowymi, Wrocław 1975.

Rosienkiewicz A., Zapobieganie i rozwiąywanie sporów między jednostkami uspołecznionymi, Wrocław 1978.

Siedlecki W., [w:] J. Jodłowski, W. Siedlecki, Postępowanie cywilne. Część ogólna, Warszawa 1958.

Siedlecki W., Postępowanie cywilne. Część szczególowa, Warszawa 1959.

Siedlecki W., Postepowanie cywilne. Zarys wykładu, Warszawa 1977.

Szanciło T., Przedsiębiorca w prawie polskim, „Przegląd Prawa Handlowego” 2005, nr 3.

Tomaszewski M., Klauzule arbitrażowe w kontaktach handlu zagranicznego sektora nieuspołecznionego, „Handel Zagraniczny” 1984, nr 2.

Tyczka M., Arbitraż i postepowanie arbitrażowe, Warszawa 1970.

Walicki A., PRL i skok do neoliberalizmu. Jaruzelski, Solidarność, zdrada elit, Warszawa 2021.

Wengerek E., Tyczka M., Sądownictwo polubowne w handlu zagranicznym i międzynarodowym obrocie morskim, „Przegląd Ustawodawstwa Gospodarczego” 1968, nr 6.

Wiśniewski A.W., Międzynarodowy arbitraż handlowy. Status prawny arbitrażu i arbitrów, Warszawa 2011.

Wiśniewski A.W., Rozstrzyganie sporów korporacyjnych spółek kapitałowych przez sady polubowne - perspektywa ustawowego rozstrzygnięcia, cz. 1, „Prawo Spółek” 2005, nr 4.

Wiśniewski A.W., Zdolność i zdatność arbitrażowa, [w:] System prawa handlowego, red. A. Szumański, S. Włodyka, t. 8. Arbitraż handlowy, red. A. Szumański, Warszawa 2015.

Wiśniewski T., Postepowanie sądowe w sprawach gospodarczych, Kraków 1997.

Wiśniewski T., System postępowania sądowego w sprawach cywilnych z udziatem przedsiębiorców, [w:] System prawa handlowego, red. S. Włodyka, Postepowanie sadowe w sprawach cywilnych z udziałem przedsiębiorców, t. 7, red. T. Wiśniewski, Warszawa 2013.

Włodyka S., Prawo gospodarcze. Zarys systemu. Część ogólna, t. 1, Warszawa 1981.

Włodyka S., Prawo gospodarcze. Zarys systemu. Część ogólna, t. 2, Warszawa 1982.

Włodyka S., Ustawa o rozpoznawaniu przez sądy spraw gospodarczych, „Państwo i Prawo” 1990, nr 3.

Studia nad Autorytaryzmem i Totalitaryzmem 43, nr 4, 2021

(C) for this edition by CNS 


\section{Wykaz aktów prawnych}

Dekret z dnia 5 sierpnia 1949 roku o państwowym arbitrażu gospodarczym (tekst jedn. z dnia 20 lipca 1961, Dz.U. z 1961 r. Nr 37, poz. 195).

Konstytucja Polskiej Rzeczypospolitej Ludowej uchwalona przez Sejm Ustawodawczy w dniu 22 lipca 1952 roku (Dz.U. z 1952 r. Nr 33, poz. 232).

Ustawa z dnia 17 listopada 1964 roku — Kodeks postępowania cywilnego (Dz.U. z 1964 r. Nr 43, poz. 296).

Ustawa z dnia 23 października 1975 roku o Państwowym Arbitrażu Gospodarczym (Dz.U. z 1975 r. $\mathrm{Nr} 34$, poz. 183).

Ustawa z dnia 24 maja 1989 roku o rozpoznawaniu przez sądy spraw gospodarczych(Dz.U. z 1989 r. Nr 33, poz. 175).

\section{Inne}

Projekt Kodeksu postępowania cywilnego PRL, Warszawa 1955.

Projekt Kodeksu postępowania cywilnego PRL, Warszawa 1964. 